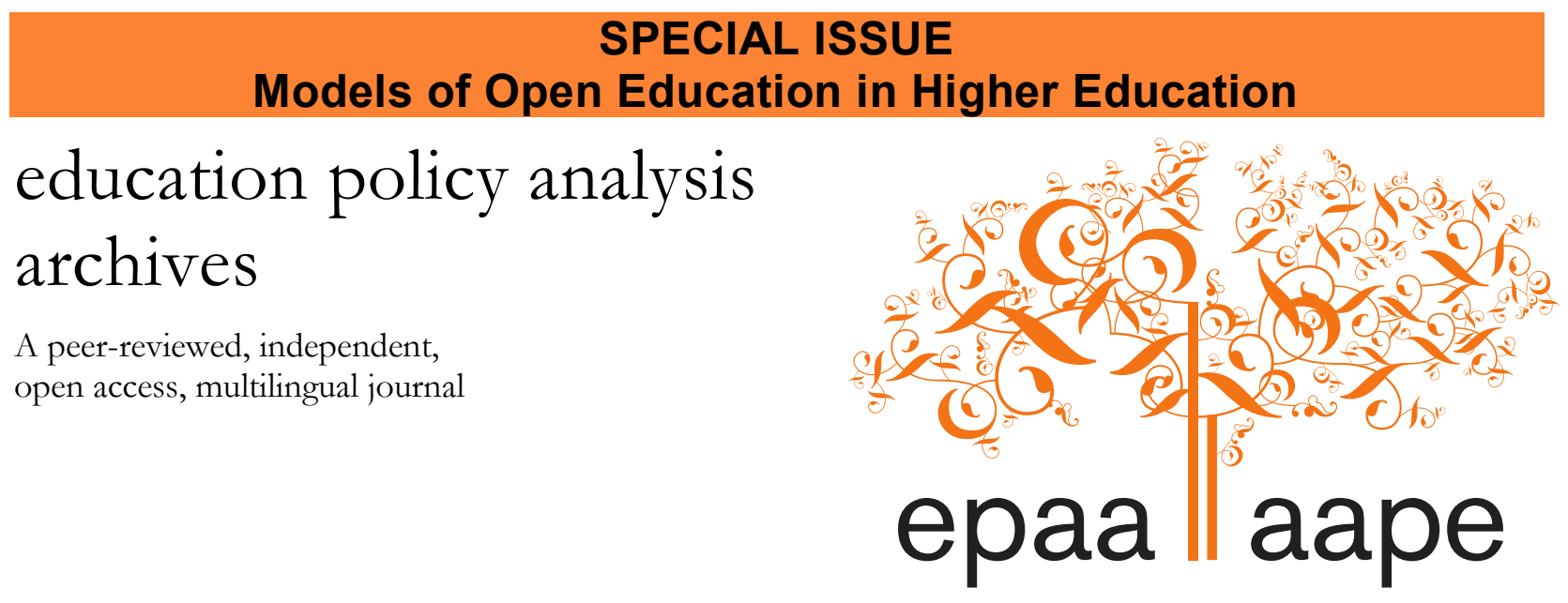

Arizona State University

\title{
Guidelines for Leveraging University Didactics Centers to Support OER Uptake in German-Speaking Europe
}

\author{
Ebner, $M$. \\ Graz University of Technology \\ Schön, S. \\ Salzburg Research Forschungsgesellschaft \\ Germany \\ \& \\ Kumar, S. \\ University of Florida \\ United States
}

Citation: Ebner, M., Schön, S., \& Kumar, S. (2016). Guidelines for leveraging university didactics centers to support OER uptake in German-speaking Europe. Education Policy Analysis Archives, 24(39). http://dx.doi.org/10.14507/epaa.24.1856 This article is part of EPAA/AAPE's Special Issue on Models of Open Education in Higher Education Guest Co-Edited by Dr. Lisa Petrides and Dr. Cynthia Jimes.

\begin{abstract}
Although less well established than in other parts of the world, higher education institutions in German-speaking countries have seen a marked increase in the number of open educational resource (OER) initiatives and in government-supported OER funding in recent years. OER implementation, however, brings with it a unique set of challenges in German-speaking higher education contexts, stemming in part from copyright laws and use permissions that have made sharing and reuse of educational materials less prevalent. The article discusses how instructional
\end{abstract}


development centers, including university didactics centers (bochschuldidaktische Zentren) and e-learning centers, can play a key role in faculty uptake and adoption of OER, and concludes by proposing a set of OER implementation guidelines that leverage the expertise and interfacing role of these centers in German-speaking countries.

Keywords: higher education; educational media; educational technology; distance education; instructional materials and practices

\section{Directrices para aprovechar de la didáctica universitaria para apoyar la implementación de REA en Europa Germano-hablante}

Resumen: Aunque menos establecido en otros partes del mundo, los contextos de educación superior de habla alemana en los últimos años han visto un marcado incremento del número de iniciativas y financiaciones por parte de gobiernos vinculadas a los recursos educativos abiertos. La implementación de los REA, sin embargo, conlleva una serie de retos únicos para los contextos de educación superior germano-hablante derivados en parte de las leyes de copyright y permisos de uso que han hecho que el reparto y la reutilización de materiales educativos sean menos frecuentes. El artículo aborda cómo los centros de instrucción, incluyendo los centros de didáctica universitaria (bochschuldidaktische Zentren) y los centros de e-learning, pueden tener un papel fundamental en facilitar el uso y la adopción de REA y concluye proponiendo un conjunto de directrices para la aplicación de REA que aprovechen la experiencia y la interconexión de estos centros en países germano-hablantes.

Palabras clave: educación superior; medios educativos; tecnología educativa; educación a distancia; materiales de instrucción y prácticas

\section{Diretrizes para aproveitamento a didática universitária para apoiar a implementação de REA em Europa de Língua Alemã}

Resumo: Ainda que é menos estabelecido em outros partes do mundo, nos últimos anos os contextos da educação superior em alemã têm tido um aumento marcado no número de iniciativas y financiamento pelo parte dos governos ligados aos recurso educacionais abertos. A implementação dos REA porem inclui uma série de desafios únicos para os contextos de educação superior em alemã, derivados em parte das leis de copyright e permissões de uso que tem o efeito que o compartilhamento e reutilização de materiais educacionais sejam menos frequentes. O artigo discuta como os centros de ensino, incluindo os centros de didáctila universitária (bochschuldidaktische Zentren) e os centros de e-learning, podem ter um papel fundamental em facilitar o uso y implementação de REA e termina propondo um conjunto de diretrizes para a aplicação de REA que aproveitem da experiência e interconexão destes centros em países de língua alemã.

Palavras chave: educação superior; meios educativos; tecnologia educacional; educação a distância; materiais de ensino y práticas

\section{Introduction}

Compared to the open educational resources (OER) movement in the English-speaking world, OER in German-speaking higher education contexts is not as well established. However, the last few years have seen a marked increase in the number of OER initiatives in German-speaking contexts (Arnold, 2012). In 2006, the European Commission co-financed the first project on OER, the Open e-Learning Content Observatory Services (OLCOS), which led to the first German language conference on OER in 2008 in Salzburg, Austria. In 2013, the first German OER 
conference was held in Berlin. More recently, direct, state-based funding was made available to OER projects in higher education--through an allocation of 2 million euros to OER research and OER initiatives by the German ministries of education in 2015.

German-speaking countries in Europe-vi\%. Germany, Austria, and parts of Switzerland and Italy-have also, over the last decade, witnessed the emergence of several initiatives to create and make OER available to educators and learners. For example, Jörg Loviscach at the University of Applied Science-Bielefelda has been publishing a collection of Creative Commons licensed lectures on YouTube since 2000. In 2012, the University of Technology-Darmstadt developed a central OpenLearnWare-Platform for hosting its collection of more than 1,000 open learning objects. In Austria, Graz University of Technology provides access to a collection of its open educational resources, including recorded lectures, which are also available via iTunesU.

Other examples of resource initiatives include Imoox.at, a platform for MOOCs (massive open online courses) launched in early 2014 and hosted by Graz University of Technologies and the University of Graz. Additionally noteworthy is the collaboratively written, award-winning textbook on technology-enhanced teaching and learning that has been freely available for download since 2011. The textbook leveraged a crowdfunding business model and "book sprints" that brought together over 260 participants to create the book in seven days (Alimucaj et al., 2014; Kaltenbeck, 2011; Schön, Ebner, \& Lienhardt, 2011). In addition to resources and platforms, special interest groups (SIGs) around OER have also emerged, including a collaborative SIG founded through the Swiss academic association, EduHub, to advise Swiss higher education institutions (HEI) on OER use and implementation.

The notion of free access to teaching and learning resources is valued in German-speaking Europe, as evidenced by public funding for most universities, which allows university students to pay either no fee at all, or only a small fee, to enroll. In the absence of fees, the cost-savings typically associated with the use of OER is not considered a means for attracting or retaining students in higher education. Yet there is recognition that OER offerings can enhance the public image and reputation of universities, and therewith play an important role in attracting public funding (Kopp, Ebner, \& Dorfer-Novak, 2014).

In spite of the recognized benefits of OER, the self-governing nature of public universities in German-speaking Europe may inhibit OER implementation. In particular, because academic freedom is highly valued in institutions of higher education, it is not possible to mandate that faculty members use specific materials, adopt certain practices, or teach in any specified way. Furthermore, research expertise is valued more highly than expertise in curriculum development or in teaching, so achieving excellence in teaching, as may be demonstrated through OER development, is not a priority for faculty.

Perhaps the most important factor for consideration in the uptake of OER by faculty in German-speaking Europe is the fact that published content is protected by copyright law without exception; public domain materials and materials used in other countries under fair use are by law prohibited in higher education institutions. Therefore, teachers cannot use content copyrighted by others in lectures, presentations, or in a learning management system in courses in higher education. While under certain restricted circumstances, there are limited opportunities to make paper and/or digital copies, copyright is always bound to the creator, and copyrighted materials cannot be used in the absence of explicit permission, terms of use, or licenses that are specified by the copyright holder. The stringency of copyright laws in German-speaking Europe has resulted in widespread use of Creative Commons licenses (including the "CC 0 " option, which is equivalent to public domain in the United States and other countries) to enable open access to educational resources. 
These legal issues are seen as a key driver for the uptake of OER in higher education: where there is no legal alternative to using existing materials, OER presents opportunities for educators to use, repurpose, and remix other instructors' materials. However, copyright laws in German-speaking Europe have also made the practices of sharing and repurposing educational materials less prevalent among academic staff because without a baseline for using others' materials as a starting point, OER uptake may be effectively inhibited. To begin to develop these practices, faculty members need time, skills, and support to produce learning materials and publish them as OER, or to integrate existing OER in their courses.

In light of these challenges, this article proposes and discusses an OER strategy within the context of HEI in German-speaking Europe. The article first addresses the OER movement in higher education, and the role currently played by centers such as hochschuldidaktische Zentren and "Elearning Centers." These centers are similar to centers for instructional support services at Englishspeaking institutions of higher education, which are responsible for faculty development and educational technology integration. The second half of this article discusses a strategy to realize the potential for these centers as key providers of support for OER uptake among HEI faculty in German-speaking Europe.

\section{OER Opportunities for University Didactics Centers}

A major barrier to the uptake and implementation of OER is the lack of knowledge among faculty members regarding legal, technical, and pedagogical issues surrounding the use, modification, and provision of OER. In this context, centers of faculty development, and especially those dealing with educational technology, can play an important role in the OER movement. In Germanspeaking universities, all aspects of teaching and learning related to faculty development are embodied in centers for Hochschuldidaktik (translated as "university didactics"). One of the largest centers for university didactics in German-speaking Europe is at the Technical University of Dortmund. More recently, "e-learning centers" have emerged to support the integration of media in teaching and learning. One such center, the Learning Lab at University of Duisburg-Essen, operates a media lab as part of its technological support for teaching and learning. Occasionally, centers for university didactics serve all of the higher education institutions within a geographical area, such as greater Berlin or the state of Hessen.

Faculty development programs offered at centers for university didactics and e-learning often focus on aspects of pedagogy, technology, and curriculum or course design for faculty (Bergquist \& Phillips, 1975; Caffarella \& Zinn, 1999; McKee, Johnson, Ritchie, \& Tew, 2013; McKee \& Tew, 2013). The literature on faculty development cites the crucial role played by centers for university didactics in support of faculty whose multiple roles and responsibilities might prevent them from educating themselves about current approaches to teaching and curriculum (Austin \& Sorcinelli, 2013). In addition to faculty development, centers for university didactics and E-learning also provide technological support for student research projects, as well as assuring the technical accessibility of course resources and their compatibility with mobile devices. Supporting learning among faculty and students, such centers are well positioned to facilitate the integration of OER into teaching and learning.

Maurek and Hilzensauer (2011), in their examination of the educational programs and training workshops on digital literacy and competencies in German-speaking Europe, note that OER is not yet a topic addressed within these programs, although the topic could be integral to existing training content focusing on, for example, copyright issues or the use of video and photos in teaching (Maurek \& Hilzensauer, 2011). The inclusion of training workshops in OER use and 
production within faculty development programs can apprise educators of the legal, technical, and pedagogical issues surrounding the use, modification, and provision of OER. In the process, they can promote the integration of OER into the HEI curriculum, thereby expanding the availability of quality resources for teaching and learning. From an organizational standpoint, it makes economical sense to leverage the expertise and interfacing role held by centers of university didactics or elearning to exploit the benefits of OER on behalf of the HEI, its students, and faculty. A strategy for doing so is proposed in the following sections of this article.

\section{Extending the Guidelines for OER in Higher Education}

In 2011, the United Nations Educational, Scientific and Cultural Organization (UNESCO), in conjunction with Commonwealth of Learning (COL), published Guidelines for open educational resources (OER) in higher education (UNESCO \& COL, 2011). The guidelines offer concrete strategies for integrating OER into higher education, broken down by key stakeholders and groups within the higher education context-from teachers and learners, to quality management administrators, to governments and policy makers. Absent, however, are centers for university didactics or e-learning, which are commonplace units in any typical higher education institution in German-speaking Europe. Responsible for technology enhanced learning, especially in regard to faculty development, university didactics centers are significant stakeholders for OER strategies in higher education in German-speaking Europe. These institutional centers occupy key positions: Their mission is to initiate and facilitate innovative developments in higher education, and they mediate between university management and faculty members.

Based on the topics and issues outlined in UNESCO and COL (2011), in conjunction with the stated missions specific to centers for university didactics or e-learning, the present authors drafted a set of revised guidelines for supporting an OER strategy by leveraging the didactics centers at institutions of higher education. The guidelines were subsequently shared with three experts who hold leadership roles within such centers—one each from Switzerland, Austria and Germany.

\section{Guidelines for OER Strategy at University Didactics Centers}

The guidelines presented here as an extension to the UNESCO and COL guidelines focus on implementation and support of OER, as well as its integration into teaching and learning through faculty development. Figure 1, below, outlines the three core strands, or fields of action, of the guidelines: internal measures, university-wide measures, and inter-university measures (see Fig. 1).

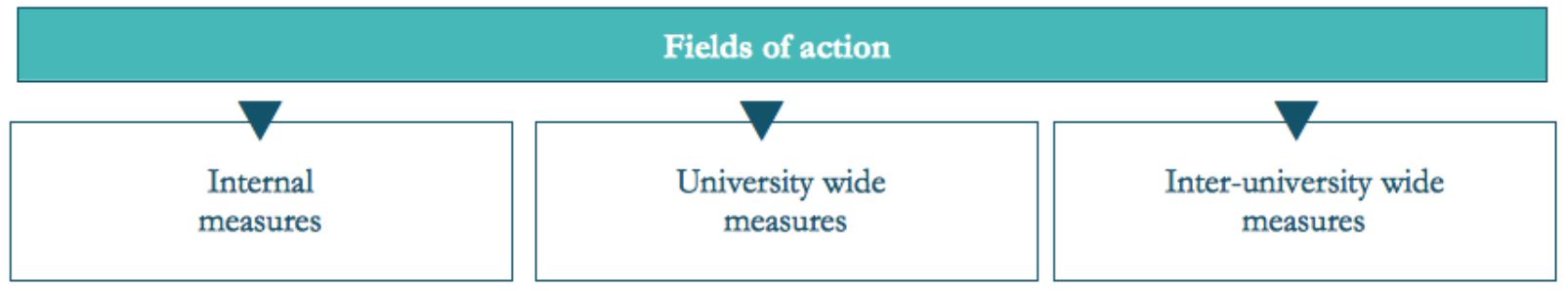

Figure. 1: Fields of action of OER implementation within university didactics centers

It is important to note that the ordering of the above-listed fields implies no particular sequence, and that the actions need not be implemented step-by-step; they may be implemented in parallel, and they are not independent from each other. Evaluation of the actions will contribute to 
continuous improvement relating to strategic purposes, such as maximizing the impact of the introduction of OER. The sections that follow address each field of action in turn.

Guidelines for internal knowledge-building measures. Members of the in-house team must first develop their own skills and knowledge around OER in order to support others in producing and using OER. The guidelines for internal knowledge building measures, outlined in Figure 2, below, identifies steps for improving the skills and networking of the in-house team in regard to OER.

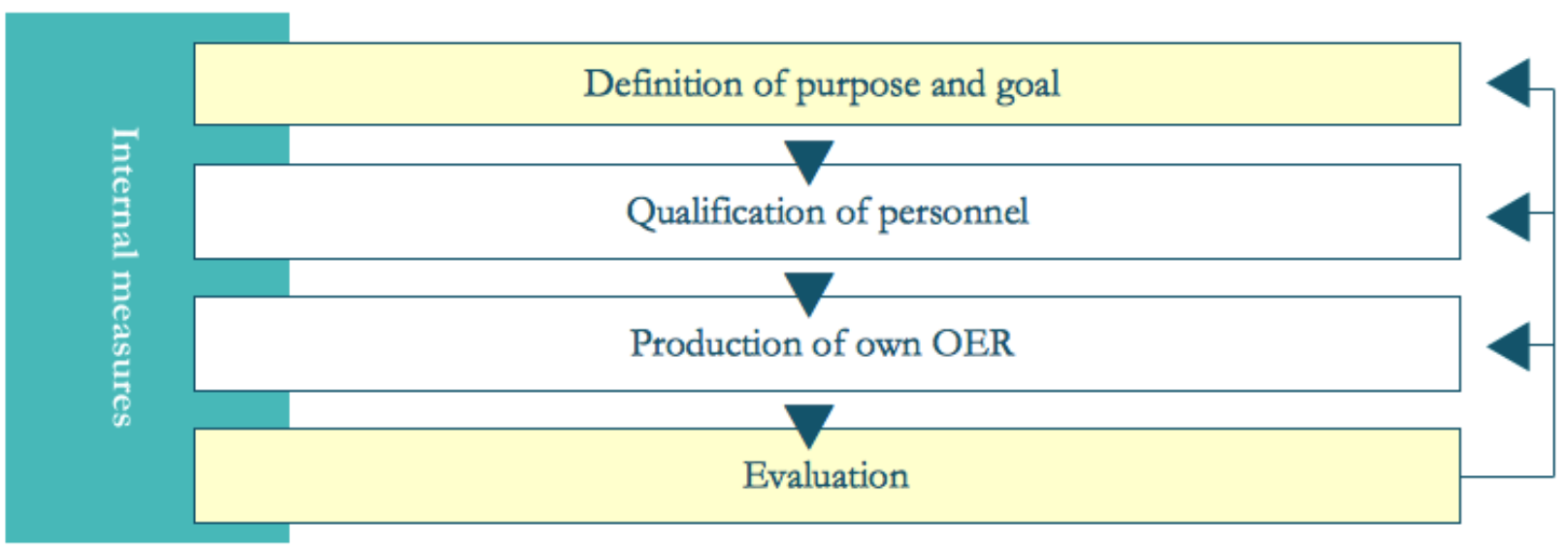

Figure 2: Guidelines for internal knowledge-building measures

Through the processes outlined in Figure 2, in-house personnel at university didactics centers become skilled and qualified in the theory and practice of OER prior to producing OER. To become qualified, personnel may take part in free online courses such as COER13.de, developed specifically for HEI didactic centers in German-speaking Europe. Furthermore, it is recommended that personnel also interact and share knowledge around their OER learning experiences with colleagues and others, as exchange and collaboration is central to OER. In addition, it is recommended that personnel also create and publish an open educational resource as part of their knowledge-building effort, with an appropriate license. The resource developed and published may center on any topic of interest to the individual.

Guidelines for university-wide measures. University-wide measures aim to assist key institutional stakeholders in the discussion toward developing a strategy that would become the basis for further OER initiatives. Guidelines for processes involved in university-wide measures are outlined in Figure 3. 


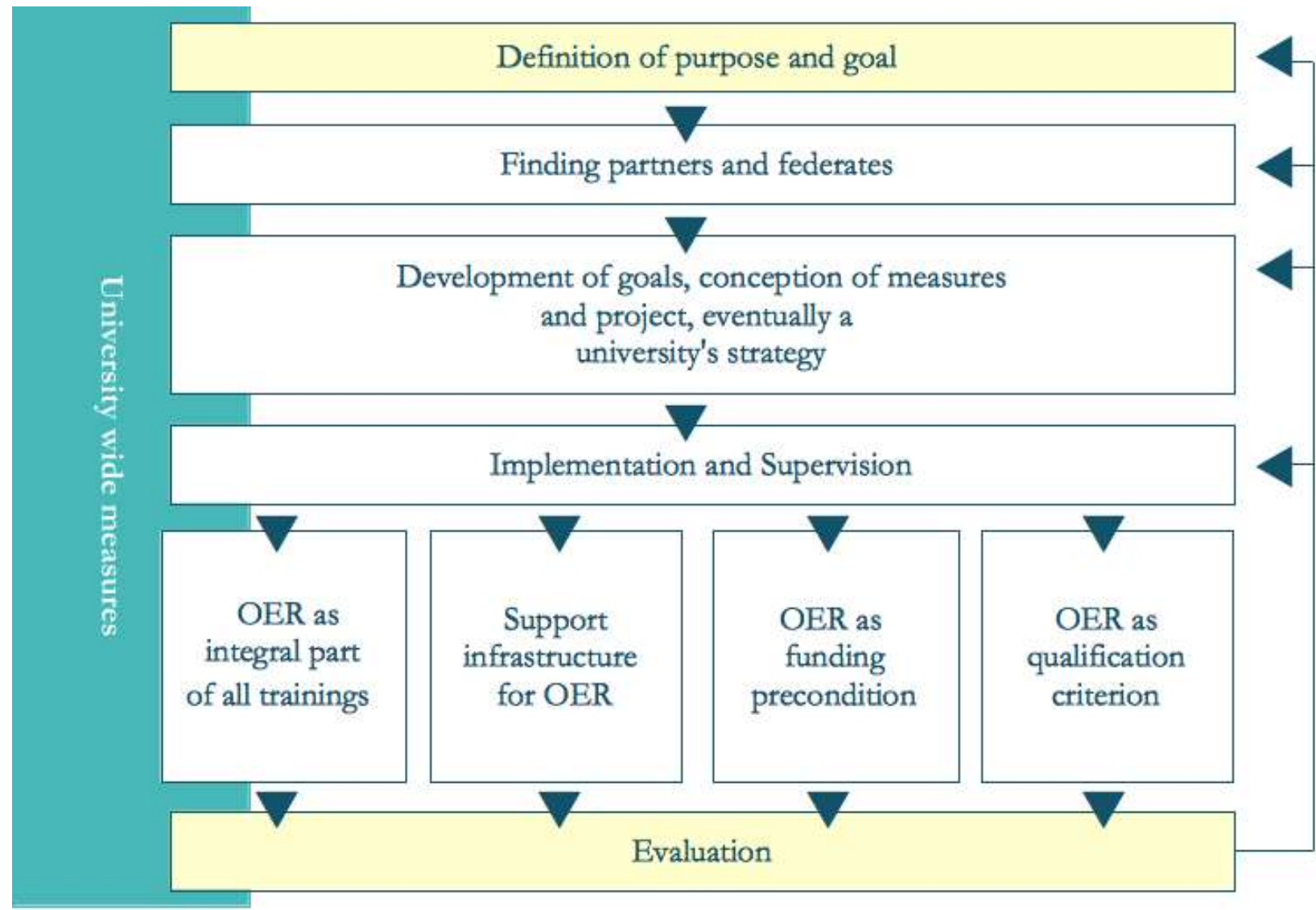

Figure 3: Guidelines for university-wide measures

In order to plan and conceive measures toward a university-wide strategy, the university must first consider its approach to OER and what the support structures will look like. The center for university didactics can act as a link between faculty members and university management in the process of developing a strategy. Additional potential partners for developing university wide measures include interested faculty who are already engaged in OER use, librarians, and deans of study (Okamoto, 2013; Reed, 2012). It is recommended that the first meeting among partners include a discussion of opportunities and challenges involved in implementing OER, as part of a larger discussion that engages partners and helps to ensure their buy-in.

At the outset, it is necessary to define the purpose and the goals of OER within the context of the institution. Based on identified and agreed upon goals, appropriate concepts and measures must be found. For example, OER may help to advance the institutional goal of promoting innovative forms of teaching and learning, which may be aligned with concepts of "education" or "open learning." OER may support exchange between institutions and/or individuals, which may align with concepts of "cooperation" or with inter-university measures to promote "open innovation." OER may help to identify new target groups, which may align with institutional measures to improve outreach. As a last example, OER may help to enhance the prestige of the university in the higher education sector, in alignment with public relations measures.

University-wide OER implementation strategy should prioritize OER as an integral part of the educational training for teachers and students. As explained earlier, the abundance of free learning materials available on the World Wide Web is of little use in German-speaking countries 
where copyright laws prevent the use or copying of such materials for educational purposes. This is perhaps one of the most important reasons why OER must be included as an important aspect of university didactics services: A basic understanding of copyright, open access, and OER license models is essential to supporting the legal use of web content among faculty and students.

University-wide measures must also include considerations regarding the installation of an appropriate technical support infrastructure, which is a prerequisite for successful use of OER. Following their production, OER need to be published in centralized repositories. A repository platform adds metadata to each single object to enhance the discoverability as well as the exchange of resources. There are innovative web technologies called APIs (Application Programming Interfaces) that allow the direct access of third party applications to accelerate the exchange of data. Ideally, learning objects are designed to be exchanged not only countrywide but also worldwide. A number of standard models for metadata have been developed to foster the exchange of learning objects, most notably the Dublin-Core-Metadata and the IEE Learning Object Metadata-Standard, on which the Österreichische Metadatensperifikation für elektronische Lehr-/Lernressourcen (Austrian Metadata specification) is based.

In order to facilitate the exchange of OER, it is important that university-funded projects or initiatives require the production and publication of OER employing standards enabling modification (for example simple TXT documents instead of PDF), as well as licenses that allow republication and modification (similar to the open access policy for scientific publications).

Promoted as a necessary teaching skill, OER creation and use can also provide valuable information regarding the quality of teaching. While text-based documents and videos may be only one indicator of good teaching, teaching materials that are available on the World Wide Web-their quality and popularity, as well as the number of reuses - can be included in criteria for high quality teaching. University didactics centers can foster quality products by supporting faculty in developing necessary skills for OER use and development. In addition, university didactics centers may offer awards to motivate faculty members to create quality OER.

Guidelines for inter-university measures. Finally, it is necessary that university didactics centers address inter-university measures, including exchange between universities, public relations, and publications. Figure 4 illustrates guidelines for these measures.

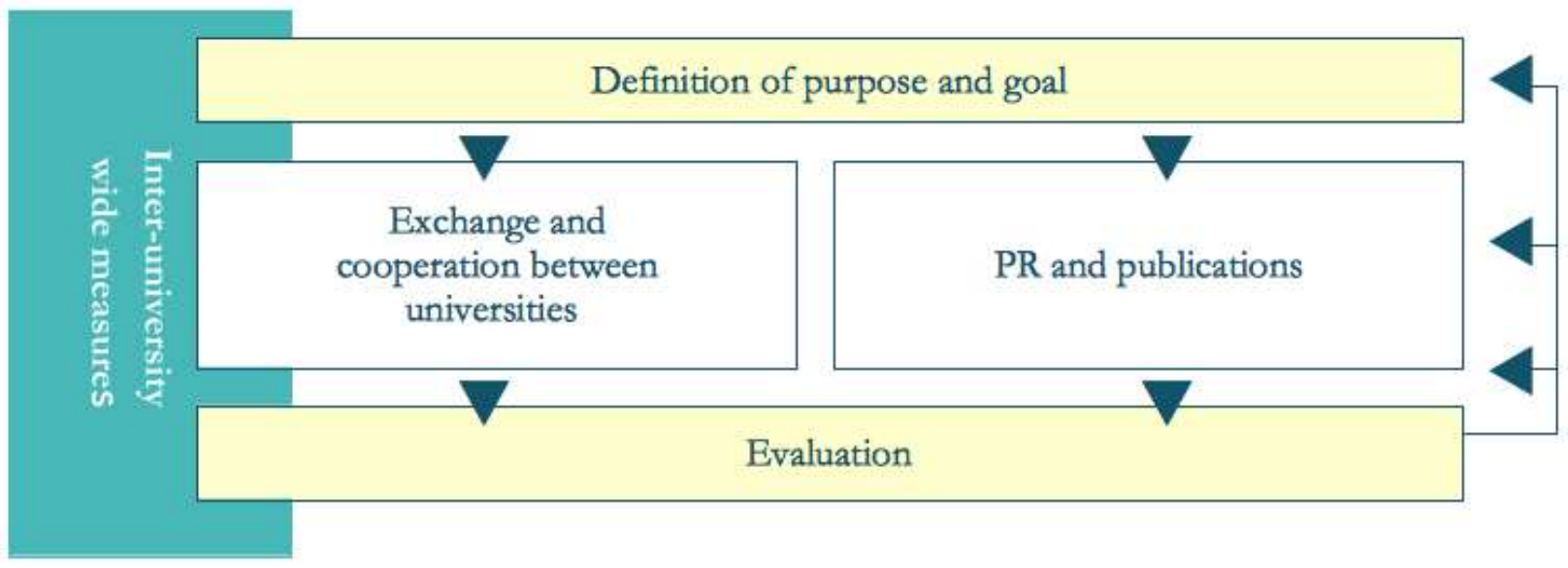

Figure 4: Guidelines for inter-university measures 
University didactics centers should actively work on OER projects, and supplement that work through conference and seminar attendance, or involvement in related OER initiatives. Copyright issues that affect faculty in their teaching are of paramount interest as a topic for an interuniversity conference or seminar. ${ }^{1}$

Conference and seminar attendance can play a central role in outreach and awareness building around OER, through public discussion of purposes and goals, as well as professional knowledge sharing around OER evaluation. Through such conduits, university didactic centers can inform other university programs and lecturers with regard to the teaching and learning benefits associated with OER.

\section{Conclusion}

This article has aimed to provide insight into the unique context and the possibilities for OER implementation in higher education institutions in German-speaking Europe. Having provided some basic understanding of that context, the article proposed a set of OER implementation guidelines that enlist the mission governing centers for university didactics or e-learning to support technology enhanced learning, especially in regard to faculty development. The proposed guidelines leverage the expertise and interfacing role inherent in these centers, developing the expertise of the HEI didactics center personnel toward supporting teaching and learning through university wide and extra-institutional measures for OER implementation.

Given existing copyright laws, OER will likely play an increasingly important role in higher education in German-speaking Europe in the future. Learners are well positioned to drive the movement, as they continue to search for resources and share them to support their learning. In parallel, debates and further work on copyright issues will strengthen institutional attention regarding OER, as witnessed by the increasing number of academic conferences and publications focusing on OER.

University didactics centers are not the only way to implement OER in higher education, and the proposal for OER strategy in German-speaking countries may not be applicable to other contexts. However, all higher education institutions with centers for instructional support or faculty development can avail themselves of the suggestions presented here, and adapt them to their specific contexts. Nevertheless, it is imperative that OER strategy at institutions of higher education include the participation of multiple stakeholders who work with faculty members, possess technical expertise, and are involved assuring the quality of teaching and learning resource materials.

\section{Acknowledgements}

The authors wish to thank Ortrun Gröblinger (E-Learning Center University Innsbruck), Ricarda Reimer (University of Applied Science-Nordwestschweiz, Head of the Special Interest Group OER at eduhub) as well as Sebastian Kelle (Senior Project officer within the department of university didactics, Stuttgart Media University) for their feedback to our first sketch of guidelines.

\footnotetext{
${ }^{1}$ In Austria, the association Forum Neue Medien in der Lebre Austria has a long tradition of examining copyright issues, as well as the topic of OER. In Germany, no such group currently exists, but may become possible in the future, in cooperation with the Gesellschaft für Medien in der Wissenschaft (Society for Media in Science).
} 


\section{References}

Alimucaj, A., Böckle, M., Ebner, M., Grossegger, M., Kaltenbeck, J., Kaltenbeck, P., Kroell, C., Leingartner, M., Lienhardt, C., Lorenz, A., Rossegger, B., Schön, S. \& Solic, G. (2012). L3T - ein innovatives Lebrbuchprojekt im Detail: Gestaltung, Prozesse, Apps und Finanzierung. Norderstedt: Book on Demand. Retrieved from http://o3r.eu

Arnold, P. (2012). Open educational resources: The way to go, or "mission impossible" in (German) higher education? In Proceedings of the Prato CIRN Community Informatics Conference 2012. Retrieved from http://ccnr.infotech.monash.edu/assets/docs/prato2012docs/arnoldfinal.pdf

Austin, A., \& Sorcinelli, M. (2013). The future of faculty development: Where are we going? New Directions for Teaching and Learning, 133, 85-97.

Baumgartner, P. (2007). Mediada-Prix - Quo vadis? Gedanken zur zukünftigen Ausrichtung des mediendidaktischen Hochschulpreises. In Forum Neue Medien in der Lehre (Ed.), ELearning. Strategische Implementierung und Studieneingang (pp. 68-81). Graz: Verlag Forum Neue Medien.

Bergquist, W. H., \& Phillips, S. R. (1975). Components of an effective components faculty development program. The Journal of Higher Education, 46(2), 177-211. http://dx.doi.org/10.2307/1980880

Caffarella, R. S., \& Zinn, L. F. (1999). Professional development for faculty: A conceptual framework of barriers and supports. Innovative Higher Education, 23(4), 241-254. http://dx.doi.org/10.1023/A:1022978806131

Cobo, C. (2013). Exploration of open educational resources in non-English speaking communities. The International Review of Research in Open and Distance Learning, 14(2), 106128.

Ebner, M., \& Stöckler-Penz, C. (2011). Open Educational Resources als Lifelong-Learning Strategie am Beispiel der TU Graz. The Lifelong Learning University, 53 - 60.

Geser, G. (2007). Open educational practices and resources. OLCOS Roadmap 2012. Salzburg: Salzburg Research.

Hylen, J. (2006). Open educational resources: Opportunities and challenges. Retrieved from http://www.oecd.org/dataoecd/5/47/37351085.pdf

Johnson, L., Levine, A., Smith, R., \& Stone, S. (2010). The 2010 Horizon Report. Austin, Texas: The New Media Consortium.

Kaltenbeck, J. (2011). Crowdfunding und Social Payments - Im Anwendungskontext von Open Educational Resources. Berlin: epubli. Retrieved from http://o3r.eu

Kopp, M., Ebner, M. \& Dorfer-Novak, A. (2014). Introducing MOOCs to Middle European universities - is it worth it to accept the challenge? International Journal for Innovation and Quality in Learning, 2(3), 46-52.

Lane, A. (2008). Reflections on sustaining open educational resources: An institutional case study. eLearning Papers, 10. Retrieved from http://www.elearningeuropa.info/files/media/media16677.pdf

Maurek, J. \& Hilzensauer, W. (2011). E-Learning-Kompetenzen entwickeln - Deutschsprachige Aus- und Weiterbildungsprogramme. In M. Ebner \& S. Schön (Eds.). Lebrbuch für Lernen und Lehren mit Technologien (L3T). Retrieved from http://13t.eu/homepage/dasbuch/ebook/kapitel/o/id/64

McKee, C. W., Johnson, M., Ritchie, W. F., \& Tew, W. M. (2001). Professional development of the faculty: Past and present. New Directions for Teaching and Learning, 133, 15-19. 
McKee, C. W., \& Tew, W. M. (2013). Setting the stage for teaching and learning in American higher education: Making the case for faculty development. New Directions for Teaching and Learning, 133, 3-14. http://dx.doi.org/10.1002/tl.20041

Okamoto, K. (2013). Making higher education more affordable, one course reading at a time: Academic libraries as key advocates for open access textbooks and educational resources. Public Services Quarterly, 9(4), 267-283. http://dx.doi.org/10.1080/15228959.2013.842397

Reed, P. (2012). Awareness, attitudes and participation of teaching staff towards the open content movement in one university. Research in Learning Technology, 20. http://dx.doi.org/10.3402/rlt.v20i0.18520

Rossegger, B. (2012). Konzept für Open Educational Resources im sekundären Bildungsbereich. Norderstedt: Book on Demand. Retrieved from http://o3r.eu

Schaffert, S. (2010). Strategic integration of open educational resources in higher education. Objectives, case studies, and the impact of Web 2.0 on universities. In U. Ehlers \& D. Schneckenberg (Eds.), Changing Cultures in Higher Education - Moving Abead to Future Learning (pp. 119-132). New York: Springer.

Schaffert, S. \& Ebner, M. (2010). Die Standortattraktivität europäischer Hochschulen fördern? Der mögliche Beitrag von Open Content. Zeitschrift für E-Learning, 5(2), 54-59.

Schön, S., Ebner, M., \& Lienhardt, C. (2011). Der Wert und die Finanzierung von freien Bildungsressourcen. In: Meißner, K. \& Engelien, M. (Eds.) Virtual Enterprises, Communities \& Social Networks, (239-250). Dresden: TUD Press.

Seufert, S. \& Euler, D. (2005). Nachhaltigkeit von eLearning Innovationen: Fallstudien zu Implementierungsstrategien von eLearning als Innovationen an Hochschulen. Arbeitsbericht 4, St. Gallen: SCIL, Universität St. Gallen.

UNESCO \& COL (2011). Guidelines for open educational resources (OER) in higher education. Retrieved from http://www.col.org/resources/publications/Pages/detail.aspx?PID=364

Wiley, D., Green, C. \& Soares, L. (2012). Dramatically bringing down the cost of education with OER-How open educational resources unlock the door to free learning. Educause. https://www.americanprogress.org/wpcontent/uploads/issues/2012/02/pdf/open education resources.pdf

Zauchner, S., Baumgartner, P., Blaschitz, E. \& Weissenbäck, A. (2008). Offener Bildungsraum Hochschule. Freiheiten und Notwendigkeiten. Münster: Waxmann. 


\title{
About the Authors
}

\author{
Martin Ebner \\ Graz University of Technology \\ mebner@gmx.at \\ Martin Ebner is currently head of Educational Technology at Graz University of Technology and \\ responsible for all university-wide e-learning activities. He holds an Associate Professorship on \\ media informatics and works also at the Institute for Information System Computer Media as senior \\ researcher. His research focuses strongly on e-learning, mobile learning, learning analytics, social \\ media and Open Educational Resources. For publications as well as further research activities, please \\ visit his website: http://martinebner.at.
}

\section{Sandra Schön}

Salzburg Research Forschungsgesellschaft sandra.schoen@salzburgresearch.at

Sandra Schön is Senior Researcher at Salzburg Research Forschungsgesellschaft in Salzburg, Austria. She coordinates research projects within the Innovation Lab (iLab). Dr. Schön's research and work focuses on OER, open data and online learning. Her website is http://sansch.wordpress.com

\section{Swapna Kumar}

University of Florida swapnaweb2@gmail.com Swapna Kumar is a Clinical Associate Professor of Educational Technology at the School of Teaching and Learning, University of Florida, USA. She coordinates the online doctoral program in Educational Technology at the College of Education and teaches graduate courses on online learning, blended learning, and educational technology research. Dr. Kumar's research focuses on the design, development, facilitation, and evaluation of online programs.

\section{About the Co-Guest Editors}

\section{Lisa A. Petrides}

Institute for the Study of Knowledge Management in Education

lisa@iskme.org

Lisa Petrides, Ph.D. is CEO and founder of the Institute for the Study of Knowledge Management in Education (ISKME). A former professor in the Department of Organization and Leadership at Columbia University, Teachers College, her research and teaching interests include information science, decision-making, and issues of access and equity in education. Petrides also leads OER Commons (www.oercommons.org), a digital public library of open educational resources, and a collaboration platform that supports and facilitates the creation, sharing, and modification of open educational resources. Petrides received her Ph.D. from Stanford University.

\section{Cynthia M. Jimes}

Institute for the Study of Knowledge Management in Education cynthia@iskme.org 
Cynthia Jimes, Ph.D., is Director of Research at the Institute for the Study of Knowledge Management in Education (ISKME), where she has led international projects over the past 10 years focusing on the use and impact of open educational resources on teaching and learning. While living in Sweden and the Netherlands from 1995 to 2004, she worked in both the private and public sectors, holding positions in research consulting, teaching high school and college, and obtaining her Ph.D. in Information Science from Uppsala University in Sweden.

\section{SPECIAL ISSUE
Models of Open Education in Higher Education education policy analysis archives}

Volume 24 Number 39
March 28, 2016
ISSN 1068-2341

\footnotetext{
(c)

SOMERIGHISRESERVED Readers are free to copy, display, and distribute this article, as long as the work is attributed to the author(s) and Education Policy Analysis Archives, it is distributed for noncommercial purposes only, and no alteration or transformation is made in the work. More details of this Creative Commons license are available at http://creativecommons.org/licenses/by-nc-sa/3.0/. All other uses must be approved by the author(s) or EPAA. EPAA is published by the Mary Lou Fulton Institute and Graduate School of Education at Arizona State University Articles are indexed in CIRC (Clasificación Integrada de Revistas Científicas, Spain), DIALNET (Spain), Directory of Open Access Journals, EBSCO Education Research Complete, ERIC, Education Full Text (H.W. Wilson), QUALIS A2 (Brazil), SCImago Journal Rank; SCOPUS, SOCOLAR (China).
}

Please contribute commentaries at http://epaa.info/wordpress/ and send errata notes to Gustavo E. Fischman fischman@asu.edu

Join EPAA's Facebook community at https://www.facebook.com/EPAAAAPE and Twitter feed @epaa_aape. 


\section{education policy analysis archives editorial board}

Lead Editor: Audrey Amrein-Beardsley (Arizona State University)

Executive Editor: Gustavo E. Fischman (Arizona State University) Associate Editors: Sherman Dorn, David R. Garcia, Oscar Jimenez-Castellanos,

Eugene Judson, Jeanne M. Powers (Arizona State University)

Cristina Alfaro San Diego State

University

Gary Anderson New York University

Michael W. Apple University of Wisconsin, Madison

Jeff Bale OISE, University of Toronto, Canada

Aaron Bevanot SUNY Albany

David C. Berliner Arizona

State University

Henry Braun Boston College

Casey Cobb University of

Connecticut

Arnold Danzig San Jose State

University

Linda Darling-Hammond

Stanford University

Elizabeth H. DeBray University of Georgia

Chad d'Entremont Rennie Center for Education Research \& Policy

John Diamond University of Wisconsin, Madison

Matthew Di Carlo Albert Shanker Institute

Michael J. Dumas University of California, Berkeley

Kathy Escamilla University of Colorado, Boulder

Melissa Lynn Freeman Adams State College

Rachael Gabriel

University of Connecticut

Amy Garrett Dikkers University of North Carolina, Wilmington

Gene V Glass Arizona

State University
Ronald Glass University of

California, Santa Cruz

Jacob P. K. Gross University of Louisville

Eric M. Haas WestEd

Julian Vasquez Heilig California State University, Sacramento

Kimberly Kappler Hewitt University of North Carolina Greensboro

Aimee Howley Ohio University

Steve Klees University of Maryland

Jaekyung Lee

SUNY Buffalo

Jessica Nina Lester

Indiana University

Amanda E. Lewis University of Illinois, Chicago

Chad R. Lochmiller Indiana University

Christopher Lubienski University of Illinois, Urbana-Champaign

Sarah Lubienski University of Illinois, Urbana-Champaign

William J. Mathis University of Colorado, Boulder

Michele S. Moses University of Colorado, Boulder

Julianne Moss Deakin

University, Australia

Sharon Nichols University of Texas, San Antonio

Eric Parsons University of Missouri-Columbia

Susan L. Robertson Bristol University, UK

Gloria M. Rodriguez

University of California, Davis
R. Anthony Rolle University of Houston

A. G. Rud Washington State University

Patricia Sánchez University of University of Texas, San Antonio Janelle Scott University of California, Berkeley

Jack Schneider College of the Holy Cross

Noah Sobe Loyola University

Nelly P. Stromquist University of Maryland

Benjamin Superfine University of Illinois, Chicago

Maria Teresa Tatto

Michigan State University

Adai Tefera Virginia

Commonwealth University

Tina Trujillo University of California, Berkeley

Federico R. Waitoller University of Illinois, Chicago

Larisa Warhol

University of Connecticut

John Weathers University of Colorado, Colorado Springs

Kevin Welner University of Colorado, Boulder

Terrence G. Wiley Center for Applied Linguistics

John Willinsky

Stanford University

Jennifer R. Wolgemuth University of South Florida

Kyo Yamashiro Claremont Graduate University 


\section{archivos analíticos de políticas educativas consejo editorial \\ archivos analíticos de políticas educativas consejo editorial}

Editor Ejecutivo: Gustavo E. Fischman (Arizona State University)

Editores Asociados: Armando Alcántara Santuario (Universidad Nacional Autónoma de México), Jason Beech, (Universidad de San Andrés), Antonio Luzon, Universidad de Granada

Claudio Almonacid

Universidad Metropolitana de

Ciencias de la Educación, Chile

Miguel Ángel Arias Ortega

Universidad Autónoma de la

Ciudad de México

Xavier Besalú Costa

Universitat de Girona, España

Xavier Bonal Sarro Universidad

Autónoma de Barcelona, España

Antonio Bolívar Boitia

Universidad de Granada, España

José Joaquín Brunner Universidad

Diego Portales, Chile

Damián Canales Sánchez

Instituto Nacional para la

Evaluación de la Educación, México

Gabriela de la Cruz Flores

Universidad Nacional Autónoma de México

Marco Antonio Delgado Fuentes

Universidad Iberoamericana,

México

Inés Dussel, DIE-CINVESTAV, México

Pedro Flores Crespo Universidad

Iberoamericana, México

Ana María García de Fanelli

Centro de Estudios de Estado y

Sociedad (CEDES) CONICET,

Argentina
Juan Carlos González Faraco

Universidad de Huelva, España

María Clemente Linuesa

Universidad de Salamanca, España

Jaume Martínez Bonafé

Universitat de València, España

Alejandro Márquez Jiménez

Instituto de Investigaciones sobre la

Universidad y la Educación, UNAM,

México

María Guadalupe Olivier Tellez,

Universidad Pedagógica Nacional, México

Miguel Pereyra Universidad de

Granada, España

Mónica Pini Universidad Nacional de San Martín, Argentina

Omar Orlando Pulido Chaves

Instituto para la Investigación

Educativa y el Desarrollo Pedagógico

(IDEP)

José Luis Ramírez Romero

Universidad Autónoma de Sonora,

México

Paula Razquin Universidad de San

Andrés, Argentina

José Ignacio Rivas Flores

Universidad de Málaga, España
Miriam Rodríguez Vargas

Universidad Autónoma de

Tamaulipas, México

José Gregorio Rodríguez

Universidad Nacional de

Colombia, Colombia

Mario Rueda Beltrán Instituto

de Investigaciones sobre la

Universidad y la Educación,

UNAM, México

José Luis San Fabián Maroto

Universidad de Oviedo,

España

Jurjo Torres Santomé,

Universidad de la Coruña, España

Yengny Marisol Silva Laya

Universidad Iberoamericana,

México

Juan Carlos Tedesco

Universidad Nacional de San

Martín, Argentina

Ernesto Treviño Ronzón

Universidad Veracruzana, México

Ernesto Treviño Villarreal

Universidad Diego Portales

Santiago, Chile

Antoni Verger Planells

Universidad Autónoma de

Barcelona, España

Catalina Wainerman

Universidad de San Andrés, Argentina

Juan Carlos Yáñez Velazco

Universidad de Colima, México 


\section{arquivos analíticos de políticas educativas conselho editorial}

Editor: Gustavo E. Fischman (Arizona State University) Editor Executivo: Gustavo E. Fischman (Arizona State University) Editoras Associadas: Geovana Mendonça Lunardi Mendes (Universidade do Estado de Santa Catarina), Marcia Pletsch, Sandra Regina Sales (Universidade Federal Rural do Rio de Janeiro)

\author{
Almerindo Afonso \\ Universidade do Minho \\ Portugal \\ Rosanna Maria Barros Sá \\ Universidade do Algarve \\ Portugal \\ Maria Helena Bonilla \\ Universidade Federal da Bahia \\ Brasil \\ Rosa Maria Bueno Fischer \\ Universidade Federal do Rio Grande \\ do Sul, Brasil

Alice Casimiro Lopes
Universidade do Estado do Rio de
Janeiro, Brasil
Suzana Feldens Schwertner
Centro Universitário Univates
Brasil
Flávia Miller Naethe Motta
Universidade Federal Rural do Rio de
Janeiro, Brasil \\ Alice Casimiro Lopes \\ Universidade do Estado do Rio de \\ Janeiro, Brasil

\section{Suzana Feld}

\author{
Alexandre Fernandez Vaz \\ Universidade Federal de Santa \\ Catarina, Brasil

\section{Regina Célia Linhares Hostins \\ Universidade do Vale do Itajaí, \\ Brasil}

Alfredo Macedo Gomes
Universidade Federal de Pernambuco
Brasil

Jefferson Mainardes

Universidade Estadual de Ponta

Grossa, Brasil

Jader Janer Moreira Lopes

Universidade Federal Fluminense e

Universidade Federal de Juiz de Fora, Brasil

Debora Nunes
Universidade Federal do Rio Grande
do Norte, Brasil

\section{Alda Junqueira Marin \\ Pontifícia Universidade Católica de São Paulo, Brasil}

Dalila Andrade Oliveira

Universidade Federal de Minas

Gerais, Brasil
José Augusto Pacheco

Universidade do Minho, Portugal

Jane Paiva

Universidade do Estado do Rio de Janeiro, Brasil

Paulo Alberto Santos Vieira

Universidade do Estado de Mato

Grosso, Brasil

Fabiany de Cássia Tavares Silva Universidade Federal do Mato

Grosso do Sul, Brasil

\section{António Teodoro}

Universidade Lusófona

Portugal

\section{Lílian do Valle}

Universidade do Estado do Rio de Janeiro, Brasil

\author{
Alfredo Veiga-Neto \\ Universidade Federal do Rio Grande \\ do Sul, Brasil
}

